\title{
IMPLEMENTASI MODEL PEMBELAJARAN THINK PAIR SHARE DAN KEBIASAAN BELAJAR TERHADAP KECERDASAN INTERPERSONAL PESERTA DIDIK KELAS X SMA(SLUA) SARASWATI I DENPASAR
}

\author{
Dewa Ayu Sri Ratnani, Ida Bagus Ari Arjaya \\ Program Studi Pendidikan Biologi Universitas Mahasaraswati Denpasar \\ E-mail : sri.ratnani67@gmail.com
}

\begin{abstract}
ABSTRAK
Tujuan penelitian iniuntuk menganalisis kecerdasan interpersonal peserta didik dengan model pembelajaran Think Pair Share(TPS) dan Kebiasaan belajar. Jenis penelitian Pre-Experimental dengan desain penelitian One Group Pretest-Postest Control Design.(Sugiyono,2016) Penelitian ini dilakukan mulai Februari - Meil 2019, bertempat di SMA (SLUA) Saraswati I Denpasar pada semester genap tahun pelajaran 2018/2019.Populasi penelitian adalah seluruh peserta didik kelas X SMA (SLUA) Saraswati I Denpasar, pengambilan sampel menggunakan teknik purposive sampling. Dengan pengambilan sampel kelas XMIA3 jumlah peserta didik sebanyak 28 orang. Variabel bebas dalam penelitian ini adalah model pembelajaran Think Pair Share (TPS) dan kebiasaan belajar. Variabel terikat penelitian adalah kecerdasan interpersonal.Pengumpulan data menggunakan instrument rubrik kecerdasan interpersonal dan angket kebiasaan belajar yang sebelumnya telah dilakukan uji validitas dan reliabilitas. Analisis data menggunakan statistik parametrik, dengan uji perbedaan rata-rata (Paired sample t-test), dan untuk uji prasyaratnya dengan menggunakan uji Normalitas. Pengolahan data dilakukan dengan menggunakan program SPSS Versi 23.0 dan program Excell. Hasil uji analisis hipotesis menunjukkan terdapat perbedaan yang signifikan terhadap kecerdasan interpersonal peserta didik sebelum dan sesudah dibelajarkan Model Pembelajaran Kooperatif Think Pair Share (TPS) dan Kebiasaan Belajar. Hasil penelitian menunjukkan secara keseluruhan kecerdasan interpersonal peserta didik berada pada kategori tinggi artinya peserta didik sudah mampu menjalin hubungan sosial dengan baik dalam pembelajaran biologi. Jadi dapat disimpulkan bahwa terjadi peningkatan kecerdasan interpersonal peserta didik kelas X MIA3 SMA (SLUA) Saraswati I Denpasar sesudah dibelajarkan Model Pembelajaran Kooperatif Think Pair Share (TPS) dan Kebiasaan Belajar.
\end{abstract}

Kata Kunci :Think Pair Share, Kebiasaan belajar,Kecerdasan Interpersonal

\section{ABSTRACT}

The purpose of this research is to analyze interpersonal intelligent of the student by think pair share (TPS) learning model and learning habbit. Various of this research is pre-experimental by one group pretest- posttest control design(Sugiyono,2016). This research was held from February-May 2019, located at SMA(SLUA) Saraswati 1 Denpasar in even semester 2018/2019.Population in this research is all of the student of X class of SMA (SLUA) Saraswati 1 Denpasar. Sample taking in this research is using purposive sampling technique. By taking sample of X MIA3 class amount 28 people. Independent variable in this research is Think Pair Share learning models and learning habbit. Dependent variable is Interpersonal intelligent.Data collecting used interpersonal intelligent rubric instrument and learning habbit quesionaire which has been treated by validity and reliability test. Data is analyzed by using parametric statistic by test average difference (Paired sample t-test) and prerequisite test by using normality test. Tabulation of data was done by using SPSS programme of 23.0 version and exell program. The result of hypothesis analysis test showed that there is the significant differency to the student Interpersonal intelligent pre and post learned think pair share model and learning habbit. The result of research showed in all of student interpersonal intelligent is in high category, its mean the student is ability to make good social relation in biology subject learning. Hence it can be concluded that there is 
increase of student interpersonal itelligent of X MIA3 class of SMA(SLUA) Saraswati 1 Denpasar after learned by think pair share (TPS) and learning habbit.

Keywords: Think pair share, learning habbit, Interpersonal intelligent

\section{PENDAHULUAN}

Seseorang mendapatkan ilmu pengetahuan dan keterampilan melalui pendidikan. Ilmu pengetahuan dan keterampilan tersebut dapat mengembangkan potensi seseorang bermula dari tidak tahu menjadi tahu, dari tidak bisa menjadi bisa dan dari tidak terbiasa menjadi terbiasa.Prinsip penyelenggaraan pendidikan bertujuan untuk mengembangkan potensi seseorang melalui budaya membaca dan menulis yang dapat mendorong seseorang untuk dapat mengembangkan minatnya. Tingkah laku seseorang berubah secara fisik, intelegensi, keterampilan, sikap, dan emosi yang menunjukkan potensi seseorang. Segala potensi, sikap, kebiasaan, kecerdasan dan perilaku sangat menentukan bagaimana nantinya seseorang berinteraksi dengan lingkungan sosialnya. Untuk itu sangatlah penting pembentukan karakter diarahkan pada kemampuan adaptasi sosial yang baik. Sebab untuk membangun hubungan sosial, potensi penyesuaian diri sangat dibutuhkan saat anak dewasa. Kenyataannya saat ini banyak orang yang menunjukkan sifat individualistiknya, hal ini tidak lepas dari pengaruh perkembangan jaman yang semakin global disertai perkembangan teknologi yang sangat pesat. Segala sesuatu dapat diakses sendiri tanpa bantuan dan interaksi dengan orang lain turut menjadi penyebab individualis seseorang. Manusia sebagai makhluk sosial tidak bisa hidup sendiri tanpa orang lain. Manusia berhubungan dengan oranglain menggunakan komunikasi verbal dan nonverbal. Sepanjang hidupnya orang akan selalu berkomunikasi dan berinteraksi dengan orang lain dan lingkungannya untuk memenuhi dan menjalani kehidupan. Individu akan bertemu dengan individu lain dan kondisi yang mempunyai karakter berbeda-beda, sehingga seorang individu memerlukan kemampuan berinteraksi. Kemampuan berinteraksi bukanlah sesuatu yang dilahirkan bersamaan dengan individu, tetapi sesuatu yang harus dikembangkan melalui pembinaan dan pengajaran. Peserta didik dituntut untuk mampu bekerjasama dan membangun hubungan yang baik.Penyesuaian pribadi dengan orang lain ataupun lingkungan sekitar perlu perhatian semua pihak terdekat, baik dari orang tua maupun para pendidik. Aspek afektif yang perlu diperhatikan untuk menunjang keberhasilan belajar peserta didik adalah kecerdasan interpersonal. Kecerdasan ini merupakan kemampuan memahami diri sendiri dan bertanggung jawab pada kehidupannya sendiri.Belajar memerlukan komitmen dan kontinyuitas yang nantinya menjadikan sebuah kebiasaan. Kebiasaan belajar adalah cara-cara yang harus dilakukan oleh peserta didik dalam kegiatan belajar dan dilakukan secara teratur dan berkesinambungan. Setiap individu memerlukan kebiasaan belajar yang efektif dalam kegiatan belajarnya yang berpengaruh terhadap pemahaman dan hasil belajar yang diraih. Hal ini dikarenakan kebiasaan merupakan cerminan perilaku seseorang 
dalam merespon sesuatu berdasarkan pemahamannya, suasana hati untuk melakukan atau tidak melakukan, menolak atau menerima sesuatu dalam belajar. Jika kebiasaan belajar peserta didik itu positif yaitu memiliki kecenderungan mau belajar dimungkinkan hasil belajarnya akan maksimal, dan sebaliknya apabila peserta didik cenderung memiliki kebiasaan yang negatif atau kurang baik maka dimungkinkan hasil belajar siswa tersebut akan kurang maksimal.Model pembelajaran adalah suatu rencana atau pola yang dapat digunakan guru dengan merancang bahanbahan pembelajaran \& membimbing pembelajaran di kelas, setiap guru harus memilih model pembelajaran yang sesuai serta efesien berdasarkan karakteristik peserta didik, kebutuhan peserta didik dan lingkungan yang dihadapi peserta didik. Think Pair Share (TPS) merupakan salah satu tipe pembelajaran kooperatif yang mampu meningkatkan kemampuan interaksi sosial pebelajar, mampu membuat suasana pembelajaran lebih interaktif dan kualitas pemahaman pebelajar lebih baik, serta pebelajar bertanggung jawab pada dirinya sendiri Harjono (2005).

Hasil observasi peserta didik pada pembelajaran biologi di SMA(SLUA) Saraswati I Denpasar masih belum mencapai nilai yang diharapkan. Hal ini dapat dilihat dari kurangnya perhatian dan partisipasi peserta didik dalam pembelajaran. Menurut observasi sementara penulis, pembelajaran yang kurang mampu mengakomodir peserta didik untuk mengontrol diri dan mengorganisasikan pengetahuannya akan membuat pembelajaran di kelas menjadi kurang bermakna yang berdampak terhadap lemahnya penguasaan konsep terhadap pelajaran yang menyebabkan peserta didik cenderung menghafal materi dibandingkan memahami dan mengaplikasikan konsep.Rendahnya partisipasi dan perhatianpeserta didik dalam pembelajaran antara lain dipengaruhi oleh faktor ketidaktepatan penerapan model pembelajaran pada peserta didik, pencapaian hasil belajar juga dipengaruhi oleh kebiasaan belajar apakah peserta didik memiliki kebiasaan belajar positif atau negatif.Kecerdasan interpersonal adalah kecerdasan yang dimiliki oleh peserta didik yang berhubungan dengan kemampuan bersosialisasi dalam kelompok. Setiap peserta didik memiliki kecerdasan interpersonal tinggi atau rendah, tugas guru lah untuk mengembangkan karakteristik kecerdasan interpersonal peserta didknya. Kurang bervariasinya model dan metode pembelajaran biologi yang digunakan guru bahkan kecenderungan penggunaan metode konvensional yang berdampak pada menurunnya hasil belajar peserta didik dan setiap individu memiliki kebiasan yang berbeda dalam belajar, kebiasaan dibangun oleh setiap pribadi siswa. Hanya saja tidak semua kebiasaan belajar bersifat positif dan mendukung pencapaian tujuan belajar. Kebiasaan belajar yang dibangun secara bebas oleh siswa sering mengarah pada posisi yang kurang layak. Sebaliknya kebiasaan belajar yang dibangun dengan kekerasan dan tekanan yang berlebihan sering menimbulkan gejolak dan penolakan dari siswa. Minimnya kecerdasan interpersonal dapat menyebabkan siswa menjadi pasif dan cenderung acuh terhadap lingkungan disekitarnya. Kecerdasan interpersonal yang rendah didalam kegiatan pembelajaran sendiri menyebabkan siswa kurang mampu bekerjasama dengan siswa lain cenderung pasif, dijauhi, serta kurang 
mampu berinteraksi dengan guru serta siswa lain.Terbatasnya kemampuan guru dalam mengembangkan pembelajaran yang menarik dan bermakna bagi peserta didik dan pelaksanaan pembelajaran pada umumnya masih didominasi oleh kegiatan guru Salah satu dampak dari model pembelajaran semacam ini adalah kreativitas berpikir peserta didik dan kemampuan peserta didik untuk menguasai keterampilan interpersonal, seperti kemampuan berkerja dalam tim, dan melakukan negosiasi kurang berkembang.

Majid, Abdul (2014) menyatakan bahwa metode Think-Pair-Share(TPS) merupakan metode yang efektif untuk mengubah pola diskusi di dalam kelas. Metode Think-PairShare(TPS) memiliki prosedur untuk memberi peserta didik waktu untuk lebih banyak berpikir, menjawab dan saling membantu dengan siswa lain. Metode ThinkPair-Share (TPS) memiliki ciri khas yang dapat membedakan dengan metode pembelajaran kooperatif lainnya ialah pairing yakni berdiskusi secara berpasangan. Surayya, Subagia \& Tika (2014) menyatakan bahwa pada tahap pair, siswa akan berpasangan untuk mendiskusikan hasil berpikir mereka sebelumnya, dan dalam berdiskusi tersebut memerlukan keterampilan berpikir diantaranya mengenal masalah, mengumpulkan informasi yang diperlukan, menganalisis data serta membuat kesimpulan. Think Pair Share (TPS) adalah salah satu jenis pembelajaran kooperatif yang dapat mengembangkan keterampilan komunikasi oral yaitu (Raba, 2017). Tint dan Nyunt dalam Tania Tamara (2018) mengatakan bahwa "Think, Pair and Share is the activity prompt pupil to reflect on an issue or problem and then to share that thinking with others". Sementara itu Boleng (2014) menjelaskan dalam penelitiannya bahwa model pembelajaran kooperatif Think
Pair Share secara signifikan berpengaruh terhadap sikap sosial dan meningkatkan kemampuan berpikir kritis.

Menurut Kamus Besar Bahasa Indonesia (2016), cerdas berarti sempurna perkembangan akal budi seseorang manusia untuk berpikir, mengerti, tajam pikiran dan sempurna pertumbuhan tubuhnya. Howard Gardner (Yaumi Muhammad, 2013) kecerdasan adalah (1) kemampuan untuk memecahkan suatu masalah, (2) kemampuan untuk menciptakan masalah baru untuk dipecahkan, dan (3) kemampuan untuk menciptakan sesuatu atau menawarkan suatu pelayanan yang berharga dalam suatu kebudayaan masyarakat. Howard Gardner menetapkan ada 10 jenis kecerdasan majemuk yaitu kecerdasan bahasa, kecerdasan logik-matematik, kecerdasan visual-spasial, kecerdasan kinestetik, kecerdasan musikal, kecerdasan interpersonal, kecerdasan intrapersonal, kecerdasan naturalis, kecerdasan eksistensial, dan kecerdasan spiritual.Kecerdasan interpersonal adalah kemampuan anak dalam menjalin komunikasi secara efektif, mampu berempati secara baik, dan kemampuan mengembangkan hubungan yang harmonis dengan orang lain.Anak-anak perlu melakukan interaksi dengan lingkungan dan teman sebaya. Kecerdasan interpersonal sangat penting untuk menjadi pribadi yang sadar secara sosial dan mampu menyesuaikan diri pada lingkungan. Apabila siswa tidak bisa mengembangkan kecerdasan interpersonalnya, akan menemui hambatan dalam perkembangan sosial dalam bermasyarakat nantinya.

Ada beberapa alasan pentingnya kecerdasan interpersonal dimiliki oleh peserta didik karena kecerdasan ini bukan hanya penting 
tetapi dasar bagi kesejahteraan peserta didik, khususnya bagi kehidupannya di masa mendatang, yaitu untuk menjadi orang dewasa yang sadar secara sosial dan mudah menyesuaikan diri, menjadi berhasil dalam pekerjaan dan demi kesejahteraan emosional dan fisik.(May Lwin,2008).Menurut Monawati (2015) bahwa anak yang memiliki kecerdasan interpersonal yang baik memiliki karakteristik yang baik pula, di antaranya: memiliki kemampuan berkomunikasi, mampu memecahkan suatu masalah, mampu bekerjasama dengan orang yang mempunyai latar belakang yang beragam, memiliki rasa empati terhadap orang lain, dan memiliki rasa peka terhadap orang sekitar.Menurut Safaria.T (2005) kecerdasan interpersonal adalah kemampuan dan keterampilan seseorang dalam menciptakan relasi, membangun relasi dan mempertahankan relasi sosialnya sehingga kedua belah pihak berada dalam situasi saling menguntungkan. Aspek dan Indikator Kecerdasan Interpersonal, Safaria menjelaskan bahwa ada tiga dimensi atau aspek kecerdasan interpersonal, yaitu sebagai berikut: 1) Social sensitivity atau sensitivitas sosial, yaitu kemampuan individu untuk mampu merasakan dan mengamati reaksi-reaksi atau perubahan orang lain yang ditunjukkannya baik secara verbal maupun non-verbal. Individu yang memiliki sensitivitas sosial yang tinggi akan mudah memahami dan menyadari adanya reaksi-reaksi tertentu dari orang lain, entah reaksi tersebut positif ataupun negatif. Dari penjelasan di atas dapat disimpulkan bahwa social sensitivityberkaitan erat dengan kemampuan individu yang meliputi: a) Sikap Empati. b) Sikap prososial. 2) Social insight, yaitu kemampuan individu untuk memahami dan mencari pemecahan masalah yang efektif dalam suatu interaksi sosial, sehingga masalah-masalah tersebut tidak menghambat apalagi menghancurkan relasi sosial yang telah dibangun individu tersebut. Semua penjelasan di atas dapat disimpulkan bahwa social insight berkaitan erat dengan kemampuan individu yang meliputi: a) Berkembangnya kesadaran diri b) Pemahaman situasi sosial dan etika sosial c) Pemecahan masalah efektif 3) Social communication atau penguasaan keterampilan komunikasi sosial merupakan kemampuan individu untuk menggunakan proses komunikasi dalam menjalin dan membangun hubungan interpersonal yang sehat. Dari penjelasan di atas dapat disimpulkan bahwa Social communication berkaitan erat dengan kemampuan yang meliputi: a) Kemampuan berkomunikasi dengan santun. b) Kemampuan mendengarkan efektif. Pada penerapan kurikulum 2013 siswa dituntut untuk lebih aktif dan mandiri dalam belajar. Oleh karena itu siswa harus selalu melatih dan meningkatkan kecerdasan interpersonal mereka, karena dengan kecerdasan interpersonal yang baik mereka dapat membangun hubungan baikdengan guru dan siswa lain, sehingga jika mereka mengalami kesulitan maka mereka tidak malu atau enggan untuk bertanya pada guru atau teman. Menurut Amstrong(2002), Ciri-ciri dari peserta didik yang memiliki kecerdasan interpersonal adalah suka bersosialisasi dengan teman seusianya, berbakat menjadi pemimpin, menjadi anggota klub, panitia, atau kelompok informal di antara teman seusianya, mudah bergaul, senang mengajari anak-anak lain secara informal, suka bermain dengan teman seusianya, mempunyai dua atau lebih teman dekat, memiliki empati yang baik atau memberi perhatian lebih kepada orang lain, banyak disukai teman dan dapat memahami maksud 
orang lain walaupun tersembunyi. Monawati (2015) berpendapat bahwa anak yang memiliki kecerdasan interpersonal yang baik memiliki karakteristik yang baik pula, di antaranya: memiliki kemampuan berkomunikasi, mampu memecahkan suatu masalah, mampu bekerjasama dengan orang yang mempunyai latar belakang yang beragam, memiliki rasa empati terhadap orang lain, dan memiliki rasa peka terhadap orang sekitar.

Ardiansyah dalam Rohman(2012) menyatakan kebiasaan belajar adalah keteraturan berperilaku yang otomatis dalam belajar yang dapat dilihat dan diukur dari keseringan atau frekwensi melakukan kegiatan yang merupakan kebiasaankebiasaan belajar yang baik dan ditunjukkan dengan indicator-indikator berikut: a) Mempersiapkan diri dalam mengikuti pelajaran; b) Memantapkan materi pelajaran; c) Menghadapi tes. Kebiasaan belajar adalah proses pembentukan kebiasaan-kebiasaan perbuatan baru atau perbaikan dari kebiasaan-kebiasaan yang telah ada,tujuannya agar siswa memperoleh sikapsikap dan kebiasan perbuatan baru yang lebih tepat dan positif dalam arti selaras dengan kebutuhan ruang dan waktu(Muhibbin,2011). Setiap individu memiliki kebiasan yang berbeda dalam belajar, kebiasaan dibangun oleh setiap pribadi siswa. Hanya saja tidak semua kebiasaan belajar bersifat positif dan mendukung pencapain tujuan belajar. Kebiasaan belajar yang dibangun secara bebas oleh siswa sering mengarah pada posisi yang kurang layak. Menurut Covey (2001) bahwa kebiasaan akan menjadikan seseorang sukses atau menghancurkannya, dan kebiasaan akan membentuk suatu karakter. Sikap dan kebiasaan belajar yang positif akan membentuk karakter yang baik seperti rajin, tekun dan disiplin, tangguh dalam menghadapi hal-hal yang mengganggu kegiatan belajar (bila menghadapi kesulitan belajar, hambatan emosional, masalah remaja dan stress dan sebagainya), serta produktif, begitu pula sebaliknya. Sikap dan kebiasaan belajar tidak hanya mempengaruhi prestasi belajar, tetapi juga akan mempengaruhi karakter seseorang.Penelitian Kunal dalam Ukpong (2013) yaitu mengenai jam belajar mandiri. Siswa yang memiliki jam belajar lebih lama (di atas 1 jam) memiliki hasil belajar yang lebih baik, kemudian memilih tempat belajar yang baik, belajar dengan menggunakan berbagai sumber, membaca secara baik dan sesuai dengan kebutuhan, bertanya untuk hal-hal yang tidak diketahui pada guru, teman atau siapa pun. Menurut M. Hasyim Ansari Berutu dan M. Iqbal $\mathrm{H}$ Tambunan(2018) semakin baik kebiasaan belajar yang dilakukan oleh siswa maka akan semakin tinggi pula hasil belajar yang dicapainya hal ini juga mengisyaratkan bahwa kebiasaan belajar yang efektif akan berdampak positif terhadap hasil belajar siswa.

\section{METODE PENELITIAN}

Jenis penelitianPra-Eksperimen(PreExperimental) dengan desain penelitian One Group Pretest-Postest Control Design.(Sugiyono,2016).Penelitian ini dilakukan mulai Februari - Meil 2019, bertempat di SMA (SLUA) Saraswati I Denpasar pada semester genap tahun pelajaran 2018/2019.Populasi dalam penelitian ini adalah seluruh peserta didik 
kelas X SMA (SLUA) Saraswati I Denpasar, teknik pengambilan sampel dalam penelitian ini menggunakan teknik purposive sampling. Dengan pengambilan sampel kelas XMIA3 dengan jumlah peserta didik sebanyak 28orang. Variabel bebas dalam penelitian ini adalah model pembelajaran Think Pair Share(TPS) dan kebiasaan belajar. Variabel terikatnya adalah kecerdasan interpersonal. Data hasil penelitian meliputi: 1) data kebiasaan belajar biologi diperoleh dengan menggunakan angket kebiasaan belajar dengan 4option jawaban, dan 2) data kecerdasan interpersonal siswa, diperoleh menggunakan tes kecerdasan interpersonal dengan 4 option jawaban. Pengumpulan data dilakukan dengan instrument rubrik kecerdasan interpersonal dan angket kebiasaan belajar yang sebelumnya telah dilakukan uji validitas dan reliabilitas. Analisis data dengan pengujian hipotesis melalui statistik parametrik, dengan uji perbedaan ratarata(Paired sample t-test), dan untuk uji prasyaratnya dengan menggunakan uji Normalitas. Pengolahan data dilakukan dengan menggunakan program SPSS Versi 23.0 dan program Excell.

\section{HASIL DAN PEMBAHASAN}

\section{Hasil Penelitian}

\section{Deskripsi Kecerdasan Interpersonal peserta didik}

Hasil uji validitas dilakukan terhadap 30 butir pernyataan pada angket kebiasaan belajar diperolehhasil 30 butir pernyataan angket dinyatakan valid. Jadi 30 butir tersebut yang digunakan sebagai instrument penelitian. Dan berdasarkan uji reliabilitas yang dilakukan menggunakan Alpha Cronbachmenunjukkan hasil bahwa $\mathrm{r}$ hitung> $r$-tab $=0.374$ dengan $\quad \mathrm{N}=28$.Jadi angket dinyatakan reliabel.

Deskripsi umum hasil penelitian sebelum dan sesudah penerapan model pembelajaran Think Pair Share (TPS)dan Kebiasaan Belajar mencakup jumlah total, nilai ratarata, standar deviasi (SD), nilai pre test dan nilai post test yang berada di atas nilai ratarata $(\geq \bar{X})$, dan nilai pre test dan nilai post test yang berada di bawah nilai rata-rata $(<\overline{\mathrm{X}}$ ) seperti disajikan pada tabel 1. sebagai berikut.

Tabel 1 Deskripsi Statistik Kecerdasan InterpersonalPeserta Didik

\begin{tabular}{lcc}
\hline Peserta Didik & \multicolumn{2}{c}{ Kecerdasan Interpersonal } \\
\hline & Pre Test & Post Test \\
\hline Jumlah Skor & 430 & 600 \\
Rata-rata & 15.36 & 21.43 \\
Standar Deviasi & 2.50 & 2.00 \\
$\geq \overline{\mathrm{X}}$ & 17 & 18 \\
$<\overline{\mathrm{X}}$ & 11 & 10 \\
\hline
\end{tabular}

Tabel 1. Menunjukkan peserta didik memperoleh nilai rata-rata dengan standar deviasi pre test $(15.35 \pm 2.50)$ dan nilai ratarata dengan standar deviasi post test (21.43 \pm 2.00 ). Data tersebut juga menunjukkan jumlah peserta didik yang memperoleh nilai di atas rata-rata $(\geq \bar{X})$ sebanyak 18 orang dan di bawah rata-rata $(<\bar{X})$ sebanyak 10 orang peserta didik.Hal ini menunjukkan jumlah peserta didik yang memperoleh nilai kecerdasan interpersonal di atas rata-rata hampir dua kali lipat dibandingkan jumlah peserta didik yang nilai kecerdasan interpersonalnya berada di bawah rata-rata. 
Hasil distribusi frekuensi kategori Kecerdasan Interpersonalberdasarkan nilai gain score disajikan pada tabel 2 .

Tabel 2. Distribusi Frekuensi Kategori Kecerdasan Interpersonal(gain score)

\begin{tabular}{llccc}
\hline & \multicolumn{3}{c}{ Kecerdasan Interpersonal peserta didik } \\
\cline { 2 - 4 } & \multirow{2}{*}{ No. Interval } & Klasifikasi & Gain Score & $\%$ \\
\hline & & sangat baik & 18 & 64.3 \\
1 & $\geq 0,7$ & baik & 10 & 35.7 \\
$2 \geq 0,3<0,7$ & cukup & 0 & 0 \\
3 & $<0,3$ & & \\
\hline
\end{tabular}

Data pada tabel.2.memperlihatkan bahwa terdapat perbedaan nilai gain score kecerdasan interpersonal peserta didik antara pre test dan post test. Dimanapeserta didik dapat mencapai nilai pada kategori sangat baik sebesar $64.3 \%$ dan berada pada kategori baik sebesar $35.7 \%$ dan tidak ada peserta didik dengan nilai gain score dengan kategori cukup.Hal ini berarti kecerdasan interpersonal peserta didik Kecerdasan interpersonal peserta didik didapatkan skor termasuk kategori tinggi ( $1 \pm$ SB) dengan skor terendah 17 dan skor tertinggi 24.

Pengujian persyaratan analisis uji hipotesis dengan uji perbedaan rata-rata yaitu Paired Sample T-Test; pemenuhan persyaratan bahwa data sampel berasal dari sampel berdistribusi normal yang dilakukan melalui pengujian normalitas data menggunakan Uji Kolmogorov smirnov.

Berdasarkanhasil uji normalitas diketahui nilai sig $=0.200>0.05$, dapat disimpulkan bahwa data berdistribusi normal dan Jadi syarat terpenuhiuntuk melakukan analisis uji hipotesis yaitu data harus berdistribusi normal. Denganmenggunakan uji statistik parametrik yaitu uji -t pada taraf signifikasi (2-tailed) dengan alpha 0,05 maka analisis Paired Sample T-Test pada program aplikasi SPSS versi 23.0 yang menggunakan model pembelajaran kooperatif metode Think-PairShare (TPS)dan kebiasaan belajar diperoleh dengan nilai signifikansi Kecerdasan interpersonal peserta didik (2tailed) $=0,000$ lebih kecil apabila dibandingkan dengan nilai alpha $0,05(0.000$ $<0,05)$. Hal ini dapat dikatakan bahwa Hipotesis alternatif diterima. Dengan demikian dapat dimaknai bahwa terdapat perbedaan kecerdasan interpersonal peserta didik sebelum dan sesudah dibelajarkan dengan model pembelajaran ThinkPairShare (TPS) dan kebiasaan belajar peserta didik.

Hasil rata-rata peningkatan (Gain score) kecerdasan interpersonal peserta didik menunjukkan bahwa terdapat perbedaan peningkatan kecerdasan interpersonal peserta didik sebelum dan sesudah perlakuan (treatment). Hasil penemuan tersebut menunjukkan bahwa model pembelajaran Think Pair Share(TPS)dan kebiasaan belajar berpengaruh nyata terhadap kecerdasan interpersonal peserta didik.Perbandingan nilai gain score pada aspek-aspek

Kecerdasan Interpersonaldisajikan dalam bentuk histogram pada gambar 1. 


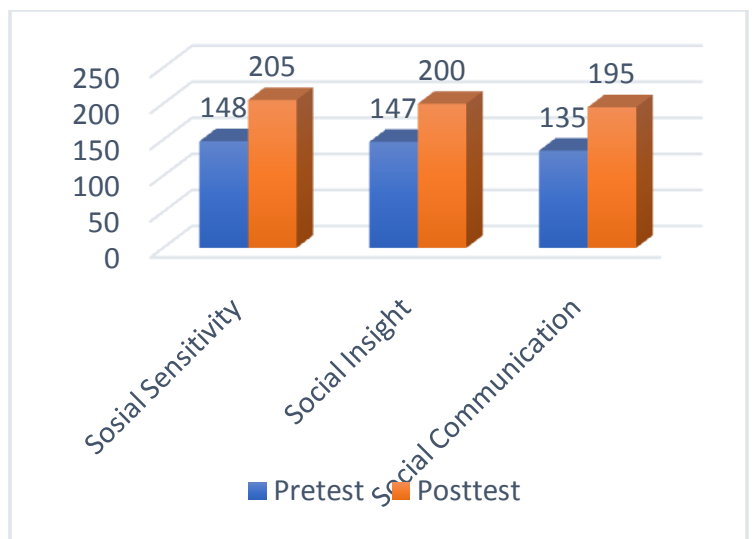

Gambar 1. Perbedaan nilai gain score kecerdasan interpersonal berdasarkan pengukuran aspek-aspek aspek Social Sensitivity(SS), Aspek Social Insight(SI), aspek Social Communication (SC.

Berdasarkan hasil analisis gain score pada masing-masing aspek yaitu Sensitivitas sosial (Social Sensitivity), pemahaman sosial (Social Insight), dan komunikasi social (Social communication) menunjukkan bahwa terdapat perbedaan nyata skor pada masing-masing aspek kecerdasan interpersonal peserta didik dimana skor tertinggi yaitu diperoleh aspekSocial Sensitivity $(S S)=0.8$, kemudian Aspek Social $\operatorname{Insight}(S I)=0.75$, sedangkan aspek dengan skor terendah adalah aspek Social Communication $(S C)=0.78$.

\section{PEMBAHASAN}

Pembelajaran biologi yang baik adalah pembelajaran yang berlandaskan pada prinsip keterampilan proses yang memungkinkan peningkatan keterampilan peserta didik untuk menemukan dan mengembangkan fakta dan konsepnya sendiri yang mampu memfasilitasi peserta didik untuk membangun pengetahuannya dan mengorganisir pengetahuannya sendiri. Kecerdasan interpersonal adalah aspek afektif yang sangat penting untuk diperhatikan dalam menunjang keberhasilan belajar peserta didik. Kecerdasan ini merupakan kemampuan memahami diri sendiri dan bertanggung jawab pada kehidupannya sendiri. Kebiasaan belajar mempengaruhi peserta didik karena keberhasilan tidaklah datang dengan sendirinya, untuk memperoleh hasil yang tinggi peserta didikpun harus berusaha keras untuk merubah kebiasaan belajarnya. Pembelajaran yang melibatkan peserta didik secara aktif dapat: 1) Meningkatkan hasil belajar peserta didik sekaligus menumbuhkan kemampuan hubungan sosial, dan mengembangkan sikap menerima kekurangan diri dan orang lain, serta 2) dapat merealisasikan kebutuhan peserta didik dalam belajar berpikir, memecahkan masalah dan mengintegrasikan pengetahuan dengan keterampilan.

Hasil analisis deskriptif memperlihatkan bahwa terdapat perbedaan nilai gain score kecerdasan interpersonal peserta didik antara sebelum dan sesudah dibelajarkan model pembelajaran TPS dan kebiasaan belajar. Dimana peserta didik dapat mencapai nilai pada kategori sangat baik sebesar $64.7 \%$ dan berada pada kategori baik sebesar 35.7\%.Dan peserta didik yang memiliki kecerdasan interpersonal di atas rata-rata mencapai 64.3\%., kecerdasan interpersonal peserta didik mendapatkan skor kategori tinggi (sangat baik =SB). Hal ini menunjukkan keberhasilan penerapan model pembelajaran Think Pair Share(TPS) dan kebiasaan belajar efektif untuk meningkatkan kecerdasan interpersonal. Kecerdasan interpersonal bisa diartikan sebagai kemampuan dan keterampilan 
seseorang dalam menciptakan relasi, membangun relasi dan mempertahankan relasi sosialnya sehingga kedua belah pihak berada dalam situasi saling menguntungkan. Situasi seperti ini dapat dibangun, dilatih dan dikembangkan secara bersama-sama antar peserta didik sebagai teman sebaya, peserta didik dengan guru, peserta didik dengan masyarakat sekolah dan lingkungannya. Interaksi yang terus menerus dilakukan oleh peserta didik terhadap komponen kecerdasan interpersonal yang meliputi komitmen, ketahanan mental, kebijaksanaan, prinsip, kepercayaan, penguasaan diri atau sinergi, empati dan pro sosial, akan mengasah kecerdasan interpersonal peserta didik sehingga berdampak terhadap peningkatan kecerdasan interpersonalnya.Didukung Maltby, et al. dalam Maryce,dkk (2015) yang menyatakan bahwa siswa dengan kecerdasan interpersonalnya akan mudah berhubungan dengan orang lain secara harmonis dan efisien, khususnya mampu untuk memahami dan berempati dengan perasaan orang lain, memperlakukan orang lain dengan kesopanan, kehangatan, dan pemahaman, dan tahu cara yang tepat memperlakukan orang lain dan menangani masalah-masalah sehari-hari yang dihadapinya. Pembelajaran kooperatif Think Pair Share(TPS)akan menumbuhkan keterampilan menjalin hubungan antarpribadi yang menekankan aspek-aspek, tenggang rasa, sikap sopan terhadap teman, mengkritik ide dan berbagai sifat positif lainnya.Belajar memerlukan komitmen dan kontinyuitas yang nantinya menjadikan sebuah kebiasaan. Kebiasaan belajar adalah caracara yang harus dilakukan oleh peserta didik dalam kegiatan belajar dan dilakukan secara teratur dan berkesinambungan. Setiap individu memerlukan kebiasaan belajar yang efektif dalam kegiatan belajarnya yang berpengaruh terhadap pemahaman dan hasil belajar yang diraih. Kebiasaan merupakan cerminan perilaku seseorang dalam merespon sesuatu berdasarkan pemahamannya, suasana hati untuk melakukan atau tidak melakukan, menolak atau menerima sesuatu dalam belajar, dan jika kebiasaan belajarnyapositif yaitu memiliki kecenderungan mau belajar dimungkinkan hasil belajarnya akan maksimal.

Hasil analisis menunjukkan sensitivitas sosial yang dicapai peserta didik tertinggi dengan kategori sangat baik yaitu sebesar $80 \%$, dan Aspek tertinggi kedua dengan prosentase sebesar $78 \%$ adalah Komunikasi sosial atau Social Comunication. Individu yang memiliki sensitivitas sosial yang tinggi akan mudah memahami dan menyadari adanya reaksi-reaksi tertentu dari orang lain, entah reaksi tersebut positif ataupun negatif. Dari penjelasan di atas dapat disimpulkan bahwa sensitivitas social(Social Sensitivity) berkaitan erat dengan kemampuan individu yang meliputi: Sikap Empati dan Sikap prososial. Kemampuan empati adalah kemampuan memahami perasaan orang lain. Misalnya pada saat siswa yang memiliki kemampuan empati yang tinggi dihadapkan pada suatu masalah dengan temannya maka ia akan berusaha untuk menyelesaikan masalah dengan cara kekeluargaan. Penyelesaian masalah dengan cara kekeluargaan diharapkan dapat membuat kedua belah pihak berada dalam situasi yang nyaman bagi dirinya maupun bagi orang lain. Peserta didik yang memiliki sikap empati 
dan sikap prososial yang tinggi memungkinkan peserta didik untuk dapat memahami dan berkomunikasi dengan temannya yang lain, melihat perbedaan mood, temperamen, motivasi dan kemampuan. Termasuk kemampuan untuk membentuk dan menjaga hubungan, serta mengetahui berbagai peranan yang terdapat dalam suatu kelompok, baik sebagai anggota maupun pemimpin. Sesuai pendapat Monawati (2015) bahwa anak yang memiliki kecerdasan interpersonal yang baik memiliki karakteristik yang baik pula, di antaranya: memiliki kemampuan berkomunikasi, mampu memecahkan suatu masalah, mampu bekerjasama dengan orang yang mempunyai latar belakang yang beragam, memiliki rasa empati terhadap orang lain, dan memiliki rasa peka terhadap orang sekitar.Sejalan dengan Howard Gardner (Yaumi Muhammad, 2013) bahwa kecerdasan interpersonal adalah kemampuan anak dalam menjalin komunikasi secara efektif, mampu berempati secara baik, dan kemampuan mengembangkan hubungan yang harmonis dengan orang lain. Anak-anak perlu melakukan interaksi dengan lingkungan dan teman sebaya. Kecerdasan interpersonal sangat penting untuk menjadi pribadi yang sadar secara sosial dan mampu menyesuaikan diri pada lingkungan. Ada beberapa alasan pentingnya kecerdasan interpersonal dimiliki oleh peserta didik karena kecerdasan ini bukan hanya penting tetapi dasar bagi kesejahteraan peserta didik, khususnya bagi kehidupannya di masa mendatang, yaitu untuk menjadi orang dewasa yang sadar secara sosial dan mudah menyesuaikan diri, menjadi berhasil dalam pekerjaan dan demi kesejahteraan emosional dan fisik. (May Lwin, 2008).
Berdasarkan hasil analisis uji paired sampel t-test terhadap kecerdasan interpersonal peserta didik diperoleh nilai $\mathrm{P} 0,000<0,05$ maka hipotesis alternatif diterima berarti terdapat perbedaan kecerdasan interpersonal peserta didik sebelum dan setelah dibelajarkan Model Pembelajaran Think Pair Share (TPS)dan kebiasaan belajar. Hal ini berarti Model Pembelajaran Think Pair Share (TPS)dan kebiasaan belajar berpengaruh nyata terhadap kecerdasan interpersonal. Perbedaan ditunjukkan oleh kecerdasan interpersonal peserta didik kelas X MIA3 SMA(SLUA) Saraswati I Denpasar meningkat setelah dibelajarkan model pembelajaran Think Pair Share (TPS) dan kebiasaan belajar. Manusia sebagai makhluk sosial tidak bisa hidup sendiri tanpa orang lain. Manusia berhubungan dengan orang lain menggunakan komunikasi verbal dan nonverbal. Sepanjang hidupnya orang akan selalu berkomunikasi dan berinteraksi dengan orang lain dan lingkungannya untuk memenuhi dan menjalani kehidupan. Individu akan bertemu dengan individu lain dan kondisi yang mempunyai karakter berbeda-beda, sehingga seorang individu memerlukan kemampuan berinteraksi. Kemampuan berinteraksi bukanlah sesuatu yang dilahirkan bersamaan dengan individu, tetapi sesuatu yang harus dikembangkan melalui pembinaan dan pengajaran. Peserta didik kelas $\mathrm{X}$ MIA 3 SMA(SLUA) Saraswati Denpasar mampu bekerjasama dan membangun hubungan yang baik, memiliki kemampuan menyesuaikan diri dengan orang lain ataupun lingkungan. Dengan mengembangkan kebiasaan belajar yang positif peserta didik seperti cara memilih sumber belajar sesuai dengan 
kebutuhan, tujuan belajar, waktu belajar, tempat belajar, suasana belajar, strategi belajar, kegiatan pada waktu belajar, serta bertanya untuk hal-hal yang tidak diketahui pada guru, teman atau siapa pun sehingga belajar menjadi lebih aktif dan dengan demikian akan memperoleh hasil yang lebih baik. Menurut Covey (2001) bahwa kebiasaan akan menjadikan seseorang sukses dan kebiasaan akan membentuk suatu karakter. Sikap dan kebiasaan belajar yang positif akan membentuk karakter yang baik seperti rajin, tekun dan disiplin, tangguh dalam menghadapi hal-hal yang mengganggu kegiatan belajar (bila menghadapi kesulitan belajar, hambatan emosional, masalah remaja dan stress dan sebagainya), serta produktif, begitu pula sebaliknya. Sikap dan kebiasaan belajar tidak hanya mempengaruhi prestasi belajar, tetapi juga akan mempengaruhi karakter seseorang. Hal ini sejalan dengan hasil penelitian Kunal dalam Ukpong (2013) yaitu mengenai jam belajar mandiri. Siswa yang memiliki jam belajar lebih lama memiliki hasil belajar yang lebih baik, kemudian memilih tempat belajar yang baik, belajar dengan menggunakan berbagai sumber, membaca secara baik dan sesuai dengan kebutuhan, bertanya untuk hal-hal yang tidak diketahui pada guru, teman atau siapa pun. Didukung oleh pendapat M. Hasyim dan M. Iqbal H.T (2018) bahwa semakin baik kebiasaan belajar yang dilakukan oleh siswa maka akan semakin tinggi pula hasil belajar yang dicapainya hal ini juga mengisyaratkan bahwa kebiasaan belajar yang efektif akan berdampak positif terhadap kecerdasan interpersonal peserta didik.
Melalui model pembelajaran Think Pair Share(TPS) peserta didik dilatih bagaimana mengutarakan pendapat dan juga belajar menghargai pendapat orang lain sehingga memungkinkan peserta didik mudah bersosialisasi dalam kelompok dan mampu menangani kesulitan dalam berkolaborasi dengan orang lain. Model pembelajaran kooperatif adalah suatu model pembelajaran yang memberikan kesempatan kepada peserta didik meningkatkan kemampuan menyelesaikan masalah dengan cara bekerja sama dengan kelompoknya untuk mencapai tujuan pembelajaran. Didukung penelitian Raba (2012) yang menyatakan bahwa Thinkpair-share memberikan kesempatan agar para peserta didik lebih aktif berpartisipasi dan berinteraksi dengan peserta didik lainnya dalam proses pembelajaran sehingga dapat membantu meningkatkan kecerdasan interpersonal. . Sesuai dengan pendapat Majid, Abdul (2014) bahwa metode ThinkPair-Share (TPS) merupakan metode yang memiliki prosedur untuk memberi peserta didik waktu untuk lebih banyak berpikir, menjawab dan saling membantu dengan siswa lain. Metode Think-Pair-Share (TPS) memiliki ciri khas yang dapat membedakan dengan metode pembelajaran kooperatif lainnya ialah pairing yakni berdiskusi secara berpasangan. Hal ini sejalan dengan pendapat Harjono (2005) bahwa model pembelajaran kooperatif mengutamakan kerja sama dalam menyelesaikan permasalahan untuk menerapkan pengetahuan dan keterampilan dalam rangka mencapai tujuan pembelajaran. Think Pair Share (TPS) merupakan salah satu tipe pembelajaran kooperatif yang mampu meningkatkan kemampuan interaksi sosial 
pebelajar, mampu membuat suasana pembelajaran lebih interaktif dan kualitas pemahaman pebelajar lebih baik, serta pebelajar bertanggung jawab pada dirinya sendiri.

Tint dan Nyunt dalam Tania Tamara (2018) juga mengatakan bahwa "Think, Pair and Share is the activity prompt pupil to reflect on an issue or problem and then to share that thinking with others". Serta Boleng (2014) menjelaskan dalam penelitiannya menunjukkan bahwa model pembelajaran kooperatifThink Pair Share secara signifikan berpengaruh terhadap sikap sosial siswa.Sifat yang tumbuh dalam diri peserta didik seperti ini memungkinkan akan terus berkembang manakala suatu hari nanti dia akan hidup dengan masyarakat yang lebih luas dan akan mudah menghargai bagaimana orang berpendapat dan menengahi bagaimana jika terjadi pertikaian diantara mereka.

\section{SIMPULAN}

Simpulan penelitian ini adalah terjadi peningkatan kecerdasan interpersonal peserta didik kelas X MIA3 SMA (SLUA) Saraswati I Denpasar sesudah dibelajarkan Model Pembelajaran Kooperatif Think Pair Share (TPS) dan Kebiasaan Belajar.

\section{DAFTAR PUSTAKA}

Abdul R.(2012), Hubungan Kebiasaan Belajar Dengan Prestasi Belajar Siswa Kelas IV SD Pada Mata Pelajaran Matematika Di Gugus V Kecamatan Wonosari Kabupaten GunungKidul, (Universitas Negeri Yogyakarta (UNY), 16-17.

Armstrong, T. 2013. Multiple Intelelligences in the Classroom Third Edition, Dyah Widya.
Boleng, D.T. (2014). "Pengaruh Model Pembelajaran Cooperative Script dan Think-Pair-Share Terhadap Keterampilan Berpikir Kritis, Sikap Sosial, dan Hasil Belajar Kognitif Biologi Siswa SMA Multietnis". Jurnal Pendidikan Sains no. 2 vol. 2 hlm. 76- 84.

Covey, Sean. (2001). 7 Kebiasaan Remaja yang Sangat Efektif (Terjemahan). Jakarta: Binarupa Aksara.

Harjono, A. (2005). Penerapan Pembelajaran Think Pair Share untuk Materi Fisika Semester 1 di Universitas Negeri Surabaya. Tesis tidak diterbitkan. Surabaya: Pascasarjana UNESA.

Hasyim,M.A.B, Iqbal H.T(2018).Pengaruh Minat dan Kebiasaan Belajar Terhadap Hasil Belajar Biologi Se Kota Stabat. Jurnal Biolokus1(7).109115

Lwin, May. et al. (2008). Cara Mengembangkan Berbagai Komponen Kecerdasan. Jakarta: Indeks.

Majid, A. (2014). "Implementasi Kurikulum 2013 Kajian Teoritis dan Praktis:. Bandung: Interes Media

Monawati, (2015). Hubungan Antara Kecerdasan Interpersonal Dengan Prestasi Belajar, Jurnal Pesona Dasar,3(3).21-32

Muhibbin Syah. 2008. Psykologi Pendidikan dengan Pendekatan Baru. Bandung: Remaja Rosdakarya

Raba, A. A. A. (2017). The Influence of Think-Pair-Share (TPS) on Improving Students' Oral Communication Skills in EFL Classrooms. Creative Education, 8, 12-23.

Safaria.T (2005). Interpersonal Intelligence: Metode Pengembangan Kecerdasan Interpersonal Anak. Yogyakarta: Amara Books. 
Sugiyono.(2012).Metode penelitian Kuantitatif Kualitatif dan $R \& D$, Bandung; Alfabeta.

Surayya, Subagia, dan Tika. (2014). "Pengaruh Model Pembelajaran Think-Pair-Share Terhadap Hasil Belajar IPA Ditinjau dari Keterampilan Berpikir Kritis Siswa". Journal Program Pasca Sarjana Pendidikan Ganesha, 4: 38-41

Tania T, Suryana, Budi S. (2018). Pengaruh Penerapan Metode Think-Pair-Share dan Group Investigation terhadap Kemampuan Berpikir Kritis Siswa (Studi Kuasi Eksperimen Pelajaran Ekonomi Pada Siswa Kelas XI SMA Negeri 3 Metro-Lampung). Indonesia Journal of Economics Education (IJEE). Program Studi Pendidikan
Ekonomi. SekolahPascasarjana Universitas Pendidikan Indonesia, 1 (1), 73-84.

Tim Penyusun Kamus Pusat Bahasa. (2005). Kamus Besar Bahasa Indonesia. Jakarta: Balai Pustaka.

Ukpong, D.E. \& George, I.N. (2013). Length of StudyTime Behaviour and Academic Achievement of Social Studies Education Students in the University of Uyo. International Education Studies; 6(3):172-178.

Yaumi, M. \& Nurdin I. (2013), Pembelajaran Berbasis Kecerdasan Jamak (Multiple Intelligences): Mengidentifikasi dan Mengembangkan Multitalenta Anak, Jakarta: Kencana 